\title{
Evolution and biodiversity in the Antarctic: the response of life to change
}

\author{
AD HUISKES \\ Netherlands Institute of Ecology, Unit for Polar Ecology, PO Box 140, 4400 AC Yerseke, The Netherlands \\ a.huiskes@nioo.knaw.nl \\ Received 18 March 2007, accepted 20 March 2007
}

As Edith Fanta has already described the IXth SCAR International Biology Symposium was special in a number of ways. Amongst these, most importantly, its title was that of a SCAR Special Research Programme, indicating a convergence of the various disciplines within Antarctic biology, hitherto operating in more than one international research program.

Until 2004 marine biologists on the one hand and terrestrial and limnetic biologists on the other operated alongside each other, with little interaction between them. Marine biological research played a dominant role in the framework of SCAR. With the collaborative research programmes BIOMASS (Biological Investigations of Marine Antarctic Systems and Stocks) and its successor EASIZ (Ecology of the Antarctic Sea Ice Zone) (Hempel 2007) the marine biologists were highly successful not least because the results were immediately applicable in developing management strategies in the framework of the Convention for the Conservation of Antarctic Marine Living Resources (CCAMLR).

In the wake of the BIOMASS program terrestrial and limnetic biologists developed the BIOTAS (Biological Investigations of Terrestrial Antarctic Systems) programme. The two programmes ran parallel to each other without any cross linkages. Although marine, terrestrial and limnetic biological research addressed similar questions (such as speciation, temperature adaptation, and metabolism) they developed largely independently from each other, despite similarities in approach. Huiskes \& Clarke (2000) suggested that this was largely due to the way in which each group conducted their research, recognizing differences both in scale and in disciplinary approach.

That may be so, but one could argue - and not for the first time - that marine, and terrestrial and limnetic ecosystems differ significantly from each other and hence require different approaches. Besides high biomass, the marine Antarctic biota has relatively high species diversity. Terrestrial and limnetic Antarctic biotas have the lowest diversity on earth. Many marine species are stenothermal organisms, evolutionarily adapted to a narrow temperature range. Terrestrial Antarctic species face temperature ranges of about $50^{\circ} \mathrm{C}$ and more, not only seasonally but also diurnally. These species also face large fluctuations in solar irradiation and rapid dehydration-rehydration cycles.

However, with the increased application of molecular techniques, and research on phylogeography and adaptive evolution executed by both groups there was clearly a need for collaboration. And yet, the SCAR EVOLANTA (Evolution in Antarctica) program, implemented in 1989, became a largely marine programme (running side by side with the SCAR program EASIZ) despite various attempts to include terrestrial and limnetic studies and the SCAR RiSCC (Regional Sensitivity to Climate Change in Antarctic Terrestrial and Limnetic Ecosystems) programme, was purely land-based, as the title indicated.

Despite this divide, the research had more in common than one would believe from the respective titles. The proceedings of the final symposium of the EVOLANTA programme (Antarctic Science 16(1) 2004) listed contributions on molecular phylogeny, genome dynamics, and protein structure and function, but also contributions on abundance, species diversity, and distribution patterns. The RiSCC program terminated its activities with the production of multi-author volume 'Trends in Antarctic Terrestrial and Limnetic Ecosystems' (Bergstrom et al. 2006) which comprised contributions on biodiversity, colonization processes, and biogeography, but also chapters on genetic studies on origin, diversity, and evolution of terrestrial organisms.

This indicated that land-based and ship-based biologists were converging in their scientific approaches.

And because of that, the transition from EVOLANTA, EASIZ, and RiSCC into EBA (Evolution and Biodiversity in the Antarctic), brought about by the restructuring of SCAR in 2002, went relatively smoothly and was hardly a landslide (or, if one prefers, a sea change).

The present special issue of Antarctic Science illustrates in part this unification process, although it is unfortunate that many of the papers were not submitted for inclusion here.

Questions on the origin of organisms in the Antarctic region were addressed by marine as well as terrestrial and limnetic biologists: Gibson \& Bayly (2007) for instance reported on the origins of crustaceans in inland waters, Murray et al. on marine picoplankton, Peat et al. reported on bryophytes and lichens, to name but a few.

Biogeography, (species) diversity, radiation and related topics were addressed in the marine realm as well as in the terrestrial and limnetic realm: a keynote address on molecular approaches (Tjede), reports on echinoids (David et al.), isopoda (Brandt et al.), and ostracoda (Brandao) from the marine system, and from the terrestrial biota, 
diatoms in moss vegetation (Van de Vijver et al.), the grass Deschampsia antarctica (Van de Wouw et al.), nematodes (Chipev et al., Convey \& Maslen), rotifers (De Smet), and lichens (Jerzy \& Beata) whilst Pearce et al. (2007) gave evidence of a bipolar distribution of lake bacteria. The application of molecular techniques in diversity studies is now well established in Antarctic and provides new insights in the origin and distribution of Antarctic organisms.

Molecular techniques are also the stock in trade of evolutionary studies (e.g. La Terza et al. 2007, Verde et al. 2007). Although evolutionary studies on Antarctic organisms are still predominantly executed on fish, we also heard presentations of studies performed on seabirds, and read posters on microorganisms and mosses.

Besides molecular techniques other sophisticated techniques are also being used nowadays in studies on community structure (ROV's, see Gutt 2007), foraging behaviour and side fidelity (e.g. Cameron et al. 2007) (stable isotopes, satellite transmitters), carbon and nitrogen fluxes (stable isotopes), and vegetation studies (remote sensing). A wide range of papers on the ecology, physiology and behaviour of seals showed very active research on these higher predators using the latest techniques.

We were treated to new approaches in selecting marine protected areas (Harris et al. 2007), new insights in monitoring and management (Reid 2007), and a comparison of the success and failures of CCAMLR and the International Whaling Commission (Kock 2007). The use of fishery data in the study of krill ecology (Kawaguchi \& Nicol 2007) provided new insights and new ways of collaboration in the management of the marine environment, an area where biologists were for a long time just the providers of baseline data in aid of the development of management plans by others. Meanwhile Hagen et al. (2007) dealt with the vexed question of krill carnivory and Quetin et al. (2007) examined the habitat variability for krill and the implications of climate change. On land there was a critique of conservation techniques implemented by the Antarctic Treaty (Walton).

And yet, the more knowledge we gather about the Antarctic biotas, the more we realise that our knowledge is, in many fields, still insufficient. Angelika Brandt and Simone Brandao made it perfectly clear that the ANDEEP cruises showed us how pitifully little we know about the deep-sea environment around Antarctica. And when it comes to the development of scenarios for change in ecosystems as a result of enhanced UV radiation and climate change the keynote papers by George Knox and Clive Howard-Williams \& Ian Hawes (2007) convinced us that for marine and inland water systems respectively, there is still much work awaiting us before realistic predictions can be made.

Indeed "Our ability to predict ecosystem responses is a test of our ability to understand ecosystem processes, structure and function", Howard-Williams \& Hawes concluded.

In conclusion one could only repeat a much-used Dutch citation:

"Hoofden van Lebak, er is veel te arbeiden in uwe landstreek!" (Leaders of Lebak, there is much work to do in your region!) (Multatuli 1860).

\section{References}

Bergstrom, D.M., Convey, P. \& Huiskes, A.H.L. eds. 2006. Trends in Antarctic terrestrial and limnetic ecosystems, Antarctica as a global indicator. Dordrecht: Springer, xii +370 pp.

Cameron, M.F., Siniff, D.B., Proffitt, K.M. \& Garrott, R.A. 2007. Sitefidelity of Weddell seals: the effects of sex and age. Antarctic Science, 19, 149-155.

Eastman, J., Gutt, J. \& Di Prisco, G., eds. 2004. Adaptive evolution of Antarctic marine organisms. Antarctic Science, 16, 1-85.

GiBSON, J.A.E. \& BAYLEY, I.A.E. 2007. New insights into the origins of crustaceans of Antarctic lakes. Antarctic Science, 19, 157-163.

GuTT, J. 2007. Antarctic macro-zoobenthic communities: a review and an ecological classification. Antarctic Science, 19, 165-181.

Hagen, W., Kawaguchi, S., Nichols, P., Nicol, S., Swadling, K.M., Virtue, P. \& Yoshida, T. 2007. A brief perspective on krill carnivory: past, present, future. Antarctic Science, 19, 183-187.

Harris, J., Howard, M., Jabour, J. \& Woehler, E.J. 2007. A new approach to selecting Marine Protected Areas (MPAs) in the Southern Ocean. Antarctic Science, 19, 189-193.

HEMPEL, G. 2007. Looking to the past: historical overview of biology in SCAR. Antarctic Science, 19, 195-203.

Howard-Williams, C. \& Hawes, I. 2007. Ecological processes in Antarctic inland waters: interactions between physical processes and the nitrogen cycle. Antarctic Science, 19, 205-217.

Huiskes, A.H.L. \& Clarke, A.C. 2000. Large scale patterns and processes - introduction. In Davison, W., Howard-Williams, C. \& BROAdY, P., eds. Antarctic ecosystems: models for wider ecological understanding. Christchurch: Caxton Press, 195-196.

KaWAGUCHI, S. \& Nicol, S. 2007. Learning about krill from the Antarctic fishery. Antarctic Science, 19, 219-230.

KocK, K.-H. 2007. Antarctic marine living resources - exploitation and its management in the Southern Ocean. Antarctic Science, 19, 231-238.

La Terza, A., Passini, V., Barchetta, S. \& Luporini, P. 2007. Adaptive evolution of the heat-shock response in the Antarctic psychrophilic ciliate, Euplotes focardii: hints from a comparative determination of the hsp 70 gene structure. Antarctic Science, 19, 239-244.

Multatuli (Eduard Douwes DekKer) 1860. Max Havelaar, or the Coffee Auctions of the Dutch Trading Company. London: Penguin Classics (1987), $352 \mathrm{pp}$.

Pearce, D.A., Cockell, C.S., Lindström, E.S. \& Tranvik, L.J. 2007. First evidence for a bipolar distributions of dominant freshwater lake bacterioplankton. Antarctic Science, 19, 245-252.

Quetin, L.B., Ross, R.M., Martinson, D., IAnnuzzi, R., Stammerjohn, S. \& Sмith, R. 2007. Ecological responses of Antarctic krill to environmental variability: can we predict the future? Antarctic Science, 19, 253-266.

REID, K. 2007. Monitoring and management in the Antarctic: making the link between science and policy. Antarctic Science, 19, 267-270.

Verde, C., Vergara, A., Giordano, D., Mazzarella, L. \& di Prisco, G. 2007. The Root effect: a structural and evolutionary perspective. Antarctic Science, 19, 271-278. 